\title{
Assay of Famotidine in Pure Solutions and Pharmaceutical Preparatives using the Coated-graphite Electrode as a Detector in the FlA System
}

\author{
Ahmed Ali Yuonis *,Shatha Yuonis Al Samarrai \\ Department of Chemistry, College of Science, University of Tikrit, Iraq (ahmedyuonis1998@gmail.com)
}

\begin{tabular}{|c|c|}
\hline Article Information & Abstract \\
\hline $\begin{array}{l}\text { famotidine, } \\
\text { coated-graphite electrode, } \\
\text { flow-injection analysis, } \\
\text { PVC-membrane. }\end{array}$ & $\begin{array}{l}\text { A simple electrochemical method was developed to estimate famotidine } \\
\text { (FMT) in pure solutions and pharmaceutical preparatives by a flow- } \\
\text { injection analysis system (FlA). This method includes preparation of a } \\
\text { coated graphite electrode using FMT with the Phosphotungstic acid } \\
\text { precipitant (PTA), di-butyl phthalate (DBP) and poly vinyl chloride } \\
\text { (PVC). The electrode characteristics were examined by studying the } \\
\text { optimum conditions, the carrier current, the injected model size, flow } \\
\text { rate, the reaction coil length, pH, the range of concentrations, the } \\
\text { minimum Nernst response, the response time, the detection limits, and } \\
\text { the study also included identifying the electrode selectivity of the } \\
\text { toward other interfering ions. The electrode showed that the best } \\
\text { Nernst slope for the calibration curve was at } 33.82 \text { mv/decade within } \\
\left.\text { linear range of (1.0 } \times 10^{-6}-1.0 \times 10^{-1} \mathrm{M}\right) \text {, correlation coefficient }\left(\mathrm{R}^{2}\right) \\
0.9999 \text {, response time } 10 \text { seconds, the estimating speed is } 90 \\
\text { sample/hour, while the rate of dilution degree (D) is } 2.6452 \text {. The } \\
\text { obtained results confirmed that it is of high accuracy and precision (Err } \\
0.119 \% \text { ), (Rec } 100.11 \%) \text {, (RSD } 0.1233 \%) \text {. The proposed method was } \\
\text { successfully applied to assay of FMT in commercial tablet forms. }\end{array}$ \\
\hline
\end{tabular}

\section{1- Introduction:}

Famotidine 3-[2-(diamino methyl eneamino) thiazol-4-yl methyl thio]-N- sulfamoyl propionamidine, Fig.1 [1]. Famotidine is the antihistamine $\mathrm{H} 2$ receptor antagonist, used to treat gastric and duodenal ulcers and gastric reflux disease [2]. Famotidine is usually given to the patient $40 \mathrm{mg}$ daily as a therapeutic nap, and Famotidine is completely absorbed by the gastrointestinal tract with a maximum concentration in the plasma about 3 hours after oral administration [3]. The literatures described various methods used to assay famotidine in the form of pharmaceutical preparatives and biological fluids such as spectrophotometric methods [4-9], chromatographic methods [10-14], the flow injection analysis method using a spectrophotometry [15], and electrochemical methods[16-18].However, most of these techniques were not particularly beneficial for assessing famotidine due to its suffering from many problems such as response time, simplicity, selectivity, efficacy, economic cost, and maximum detection. The flow injection analysis system (FlA) proved that it is an easy and appropriate way to analyze the samples due to the consumption of the reagent, the sample is low, the response time is less, the rate is high in estimating the samples, reproducibility for 
their results $[19,20]$ and can also be applied to colored and turbid solutions [21]. The aim of this work is to develop a simple, accurate and economically viable method where by the method is based on the use of ion selective electrodes as a detector in the FlA technique to assay famotidine in pharmaceutical preparatives. The work included a study of the optimum conditions and factors affecting electrode stability.

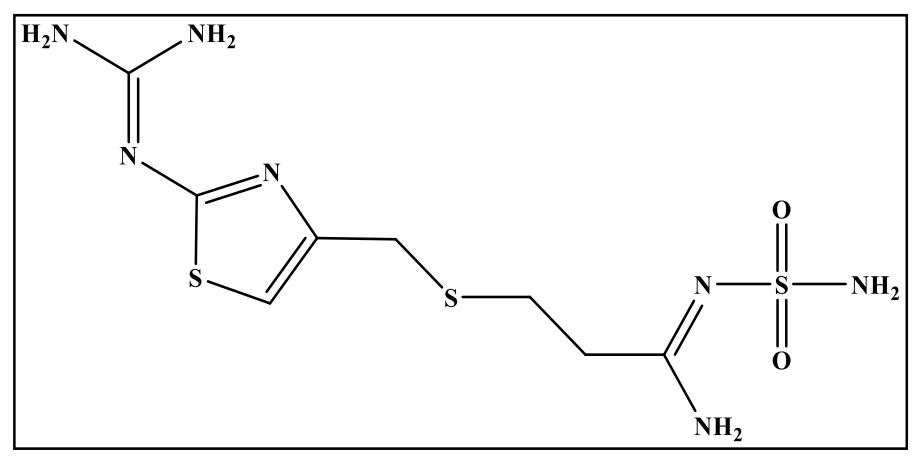

Fig. 1: The chemical structure of famotidine

\section{2- Materials and Methods}

\subsection{Apparatus}

Flow injection analysis system (FlA) Fig.2a, consists of peristaltic pump (Ismatec, IDEX comporation, Switzerland) used to pump carrier stream via polyvinyl chloride (PVC) tubes (diameter $0.5 \mathrm{~mm}$ ) commercially made and connected to the injection valve model 7125 with a change of sample loop Rheodyne from (Altexzlo, supelco, USA) works by inserting different volumes of the sample toward stream. Then it passes through the tubes of the reaction coil at which the reaction occurs. The standard calomel electrode (Hl1144B, USA) was used as an external reference electrode. $\mathrm{pH}$ meter model 3310 from (JENWAY company) works as a sensor in the (FlA) system connected to the unit of the model device C1032 (SIEMENS, kompenso, Germany) records the signal on the graphic sheet in the form of peaks. All experiments in this method operate under a single line system with a room temperature of 25.0 $1.0 \mathrm{C}^{\circ}$ and a four-decimal type sensitive balance (Balance kearm Abs 120-4).

\subsection{Reagents and Chemicals}

All the chemicals used in this study were highly pure. standard famotidine was provided by the state company for drug industries and medical appliances (SDI) Samarra -Iraq. While the forms of famotidine tablets $(20 \mathrm{mg} /$ tablet $)$ were purchased from pharmaceutical and commercial sources. phosphotungstic acid (PTA) (Fluka, Germany), poly vinyl chloride (PVC) (Fluka, Germany), diputyl phthalate (DBP) (Fluka, Germany). The solutions were prepared using double distilled water with specific conductivity, as follows: -

\subsubsection{Standard Famotidine Solution 0.1 M}

The standard solution was prepared by dissolving $3.375 \mathrm{~g}$ of famotidine in amount of $10 \%$ acetic acid. Complete the volume up to the mark with the same solvent in a $100 \mathrm{ml}$ volumetric flask to obtain of $0.1 \mathrm{M}$ concentration. This is followed by preparing a series of standard solutions with concentrations $\left(1.00 \times 10^{-7}-1.00 \times 10^{-2} \mathrm{M}\right)$ by dilution. Kept the famotidine solutions in a cool and dark place. 
a-

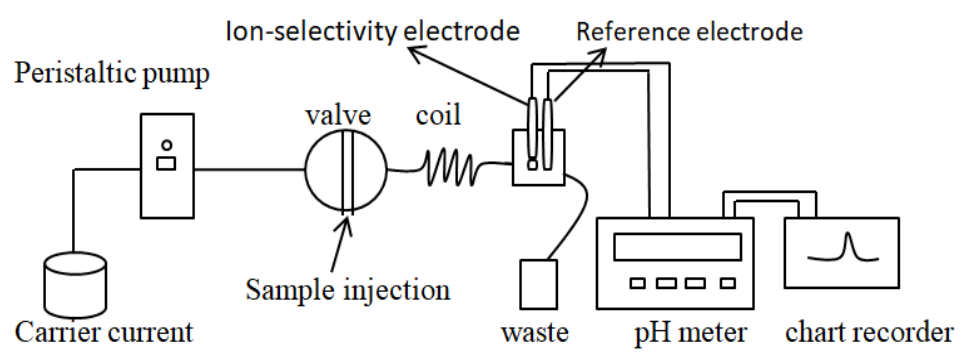

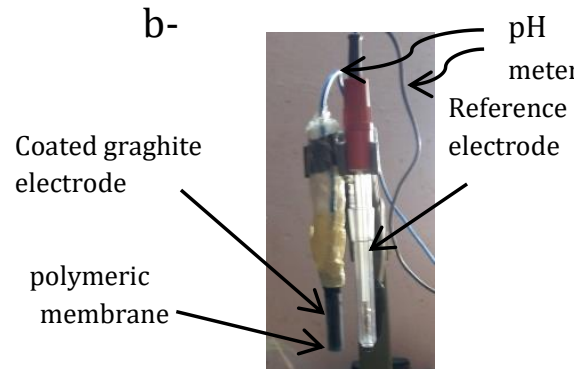

Fig. 2: $a$. Schematic diagram of the flow injection system used in famotidine measurements.

$b$. Diagram of coated-Graghite electrode and reference electrode.

\subsubsection{Phosphotungstic acid 0.1 M}

A phosphotungstic acid solution was prepared by dissolving $28.802 \mathrm{~g}$ of solution in 100 $\mathrm{ml}$ distilled water and complete the volume to the mark in a $100 \mathrm{ml}$ volumetric flask to obtain $0.1 \mathrm{M}$ concentration. Store the solution (PTA) in a cool place under a temperature of $10 \mathrm{C}^{0}$.

\subsubsection{Famotidine Preparative Solution 0.01 M}

Ten tablets of famotidine were weighed and crushed in a porcelain mortar. A concentration of $0.01 \mathrm{M}$ was prepared from the preparation containing $0.02 \mathrm{~g}$ of active ingredient by dissolution and to ensure dissolution, an ultrasound apparatus was used. Then it is filtered using Whatman filter paper No. 42 to get rid of insoluble matter and get a solution of $0.01 \mathrm{M}$ concentration. dilute the solution by using double distilled water to the required level.

\subsection{Procedure}

\subsubsection{Ion-pair Preparation}

The ionic complex was prepared by adding $30 \mathrm{ml} 1.00 \times 10^{-1} \mathrm{M}$ of famotidine to $10 \mathrm{ml}$ $1.00 \times 10^{-1} \mathrm{M}$ of the precipitant PTA with continuous stirring and a yellow-colored precipitate of FMT-PTA is formed. Filter the precipitate using filter paper No. 42 and wash it several times with double- distilled water. The precipitate is then dried at room temperature $25.0 \pm 1.0 \mathrm{CO}$ for 24 hours. Store in a cool and dark place.

\subsubsection{Preparation of the Coated-graphite electrode}

The sensitive film mixture was prepared by mixing $190 \mathrm{mg}$ of polyvinyl chloride (PVC) powder as a supported material, $10 \mathrm{mg}$ of pre-prepared ion complex, $0.35 \mathrm{~mL}$ plasticizer DBP and $5 \mathrm{ml}$ of tetrahydrofuran (THF) as a solvent [18] . The membrane mixture is placed in a small glass beaker to be used for coating the electrode surface. The graphite electrode that was previously cleaned by immersing it in sulphuric acid for 24 hours, drying it with acetone and isolating it with a tight polyethylene tube of $4.0 \mathrm{~cm}$ in length and $2 \mathrm{~mm}$ in diameter was painted throw the exposed end by dipping it in the sensitive film mixture for ten times and allowing the THF to evaporate by leaving the coated graphite electrode in the air to dry for one or two minutes at a time. After finishing the dipping process, the coated graphite electrode should be left at room temperature for a sufficient time for drying, and then placed 
in a solution of $1.00 \times 10^{-2} \mathrm{M}$ diluted FMT for 10 hours to obtain an exchange of ions. Fig. $2 b$, illustrates a sample of the coated graphite electrode.

\section{Results and Discussion:}

Many important conditions affect the electrode response in the method of flow injection analysis (FlA), therefore these conditions must be studied and apply when designing the system, the most important of which are: (carrier stream, sample volume, flow rate, reaction coil length and $\mathrm{pH}$ ).

\subsection{Optimization of FlA Response}

\subsubsection{A Carrier Current Effect}

The FlA technique essentially needs a continuous carrier current solution. Therefore, a group of solutions with a concentration of $0.1 \mathrm{M}$ (Potassium chloride, sodium nitrate, and potassium nitrate) by injecting a fixed volume of $150 \mu \mathrm{L}$ of the sample at different concentrations and a constant flow speed, the obtained results showed that potassium nitrate $0.1 \mathrm{M}$ gave the maximum peak and was chosen as the best carrier stream working with the FMT-PTA electrode. While other solutions led to a decrease in the peak and an increase in the consumption of chemicals.

\subsubsection{Effect of the Volume of the Injected Sample}

The study of the sample volume $\left(\mathrm{S}_{\mathrm{V}}\right)$ was done by changing the loop length in the injection valve and applying the following equation: -

$\mathrm{r}=$ radius in $(\mathrm{cm})$

$$
\mathrm{S}_{\mathrm{V}}=\pi \mathrm{r}^{2} \mathrm{~L}_{\mathrm{S}}
$$

Ls = loop length in $(\mathrm{cm})$

$\pi=$ fixed ratio

Different volumes were taken from the sample $(60,90,120,150,180$, and $210 \mu \mathrm{L})$ with different concentrations of FMT ranged (1.00 x 10-6 - $\left.1.00 \times 10^{-1} \mathrm{M}\right)$ and injected into the FlA system. The results obtained in Fig.3, show that the most effective sample volume for FMT which gave the maximum peak was at $150 \mu \mathrm{L}$ and is selected as the best volume of the sample with the prepared electrode.

\subsubsection{Flow Rate Effect}

A flow rate study was performed for peak using different flow rates $(0.5,1,1.5,2,2.5$ and $3 \mathrm{ml} / \mathrm{min}$ ) with a fixed sample volume of $150 \mu \mathrm{L}$, Fig.4. shows the results of the study, It showed that with increasing flow rate, the height of the peak became higher and sharp until it reached $2 \mathrm{ml} / \mathrm{min}$. then, the height of the peak began to decrease with increasing the flow rate, therefore the best flow rate of the FMT-PTA electrode was chosen at $2 \mathrm{ml} / \mathrm{min}$. 


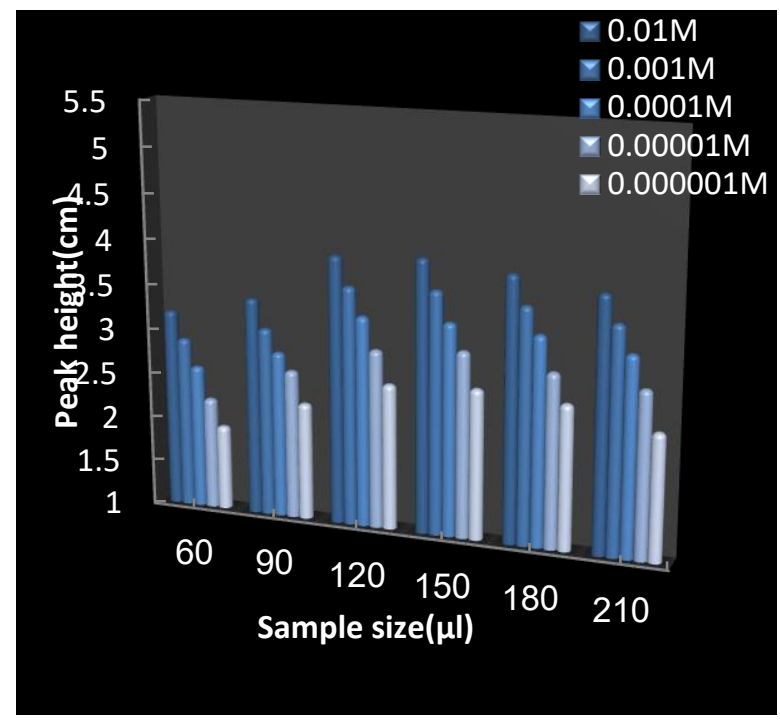

Fig . 3: Effect of Injection Volume

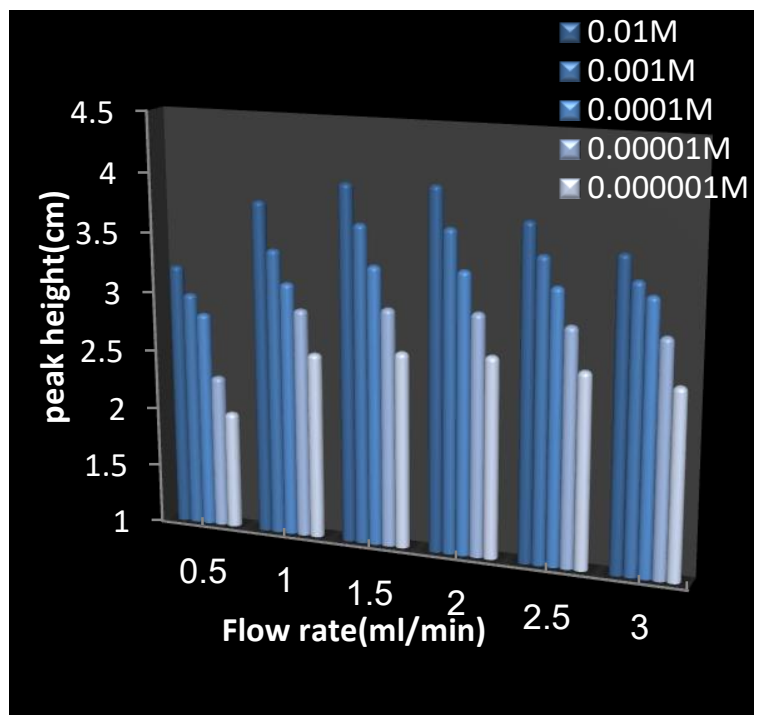

Fig . 4: Effect of Flow Rates

\subsubsection{Effect of the length of the Reaction Coil}

The length of the reaction coil has an extreme effect at the height of the peak, therefore its studies was performed by using different lengths of the reaction coil ranged as $(20,40,60,80$, and $100 \mathrm{~cm}$ ). The results obtained in Fig.5 indicate that with a decrease in the length of the reaction coil, the maximum peak was given. while increasing the length of the reaction coil, the height of the peak began to decrease, due to the increased degree of dilution of the sample. accordingly, $20 \mathrm{~cm}$ was chosen as the best length for the reaction coil to be used in subsequent studies.

\subsubsection{Effect of pH}

The effect of the FMT solution $\mathrm{pH}$ on the height of the peak was achieved by injecting a series of FMT solution via the injection valve with a different $\mathrm{pH}$ level in the FlA system. Sodium hydroxide $0.1 \mathrm{M}$ solution and $0.1 \mathrm{M}$ hydrochloric acid were used to adjust and fix the $\mathrm{pH}$ level to the real value (required). Fig.6, results obtained showed that most of the effectiveness potentiometric response of the FMT-PTA electrode can work at a pH range of (37).

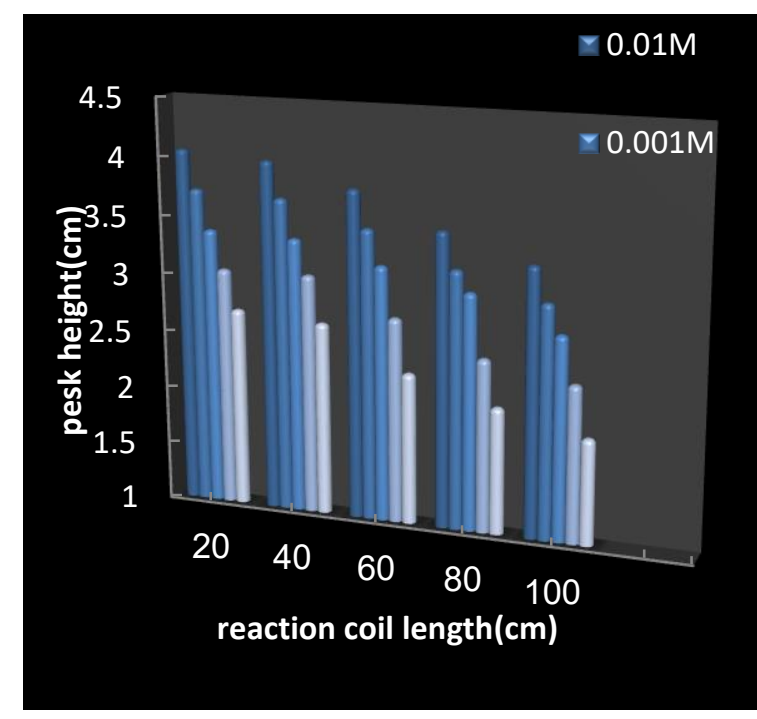

Fig. 5: Effect of Reaction Coil Length

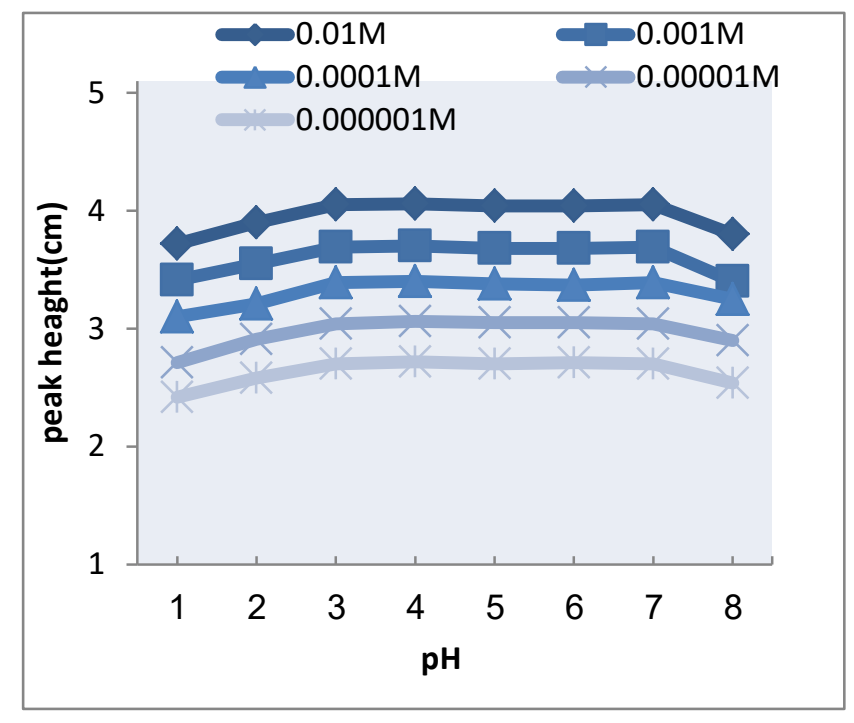

Fig. 6: Effect of $\mathrm{pH}$ 


\subsection{Calibration Curve}

To plotted the calibration curve, a series of solutions containing different drug concentrations of FMT was prepared.150 $\mu \mathrm{L}$ of each concentration of FMT solution was injected into the FlA technique under optimum conditions, Table 1 . The calibration curve represents the change in voltage (mv), that is, the height of the peak (mv) versus the change in concentrations expressed in -log [c]. Fig.7 showed that the linear range of the Nernestian response was from $\left(1.00 \times 10^{-6}-1.00 \times 10^{-1} \mathrm{M}\right)$, correlation coefficient $(0.9999)$. The slope of Nernset was equal to (33.82 $\mathrm{mv} /$ decade) and the value is close to the theoretical value calculated from the Nernest two-charge equation $(29.58 \mathrm{mv} /$ decade). This means that the drug is di charge.

\subsection{Accuracy and Precision}

Accuracy and precision were studied by calculating the relative error, recovery and the relative standard deviation. Table 2 showed the obtained results that the relative error did not exceed $0.1190 \%$, and the recovery $100.11 \%$. While relative standard deviation was $0.1233 \%$. These results prove that the method is of high accuracy and precision.

\subsection{Detection limit}

The lowest electrode-sensing concentration was taken from the standard calibration curve and injected into a carrier current solution using a plastic syringe and six consecutive times for same concentration after optimizing the conditions. The result is shown in Table 1.

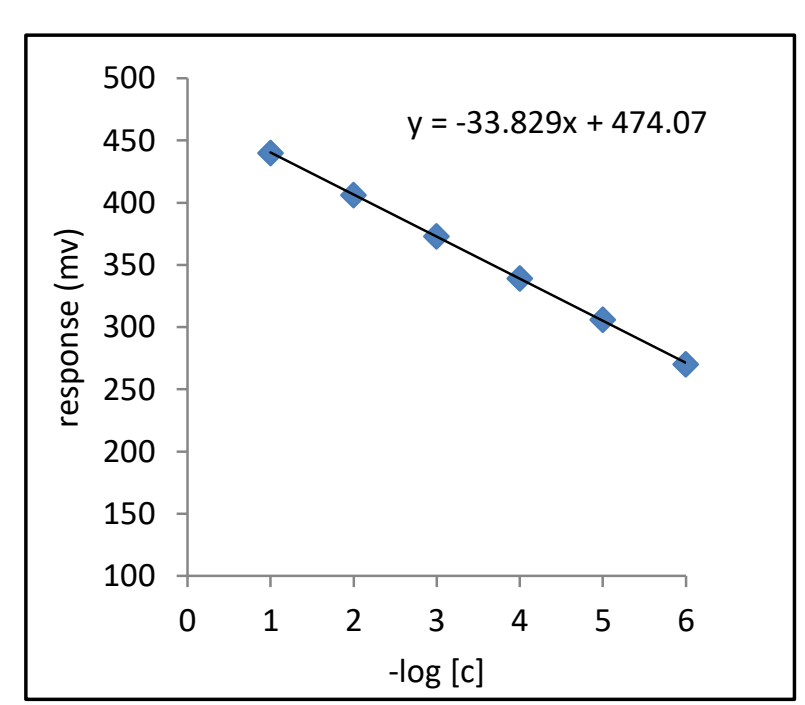

Table 1: The characteristics of the electrode

\begin{tabular}{lr}
\hline Parameter & $\begin{array}{r}\text { Famotidine } \\
\text { Electrode }\end{array}$ \\
\hline Regression equation & $\mathrm{Y}=-33.82 \mathrm{x}+474.07$ \\
Slope (mV. decade $\left.{ }^{-1}\right)$ & -33.82 \\
Linearity range[M] & $1.0 \times 10^{-6}-1.0 \times 1^{-1}$ \\
Correlation coefficient & 0.9999 \\
Nernst response [M] & $1.00 \times 10^{-6}$ \\
Detection limit & $1.24 \times 10^{-7}$ \\
The speed of sampling & 90 \\
(sample/hour) & \\
Response & 10 \\
time(second) & \\
\hline
\end{tabular}

Fig. 7: Calibration graph for famotidine

Table 2: Accuracy and precision

\begin{tabular}{cccccc}
\hline Eel & Conc $(M)$ & $\hat{z}$ & SD & RSD \% & Rec \% \\
\hline \multirow{2}{*}{$\sum_{i=}$} & $1.0 \times 10^{-2}$ & 406.483 & 0.5013 & 0.1233 & 100.11 \\
& $1.0 \times 10^{-4}$ & 338.261 & 0.3372 & 0.0995 & 99.89 \\
& $1.0 \times 10^{-6}$ & 270.184 & 0.2032 & 0.0752 & 100.06 \\
\hline
\end{tabular}

FMT: Famotidine, Ele: electrode, Conc: Concentrations, ẑ: Six consecutive read average, SD: standard deviation, RSD\%: Relative Standard Deviation, Rec\%: Recovery. 


\subsection{Comparison of theoretical Nernst slope of the FMT-PTA electrode with and without carrier current (sample injection)}

Table 3 shows the results of the comparison of the theoretical Nernst slope calculated from the Nernst equation and the experimental slope with and without injecting the sample at a flow rate of $2 \mathrm{~mL} / \mathrm{min}$ for the FMT electrode. As these values indicated a convergence between the theoretical slope of Nernst two-charge and experimental inclination in addition to that the correlation coefficient was in all cases more than 0.99 [22].

Table 3: The nearest slope for the electrode FMT-PTA

\begin{tabular}{cccccc}
\hline Ele. & Conc (M) & Speed & $\begin{array}{c}\text { Without } \\
\text { injection at teq }\end{array}$ & $\begin{array}{c}\text { With } \\
\text { injection at } \\
\text { teq }\end{array}$ & $\begin{array}{c}\text { Nernst } \\
\text { theoretical } \\
\text { slope }\end{array}$ \\
\hline FMT & $1.0 \times 10^{-6}-1.0 \times 10^{-1}$ & $\begin{array}{c}2 \\
\mathrm{~mL} / \mathrm{min}\end{array}$ & -33.51 & -33.82 & -29.55 \\
\hline
\end{tabular}

FMT: Famotidine, Ele: electrode, Conc: Concentrations, teq: time equilibrium

\subsection{Degree of Dispersion}

The degree of dispersion (D) is one of the most important factors that must be considered when designing the FlA system because it shows the amount of dilution that occurred for solutions during the period of their presence in the system from the start of injection until the results appear. The degree of dilution was calculated by passing the sample without a carrier current through the system and recording the initial response height $\left(\mathrm{H}^{0}\right)$. The process was repeated, but this time using a carrier current under the optimum conditions and recording the response height $\left(\mathrm{H}_{\max }\right)$. By applying the equation below, the dilution degree (D) was calculated.

$$
\begin{aligned}
\log \mathrm{D} & =\frac{\mathrm{H}^{\circ}-\mathrm{Hmax}}{\mathrm{S}} \ldots \ldots \ldots \ldots \ldots \ldots \ldots \ldots \ldots \ldots \ldots \ldots \ldots \ldots \ldots \ldots \ldots \ldots \ldots \ldots \ldots \ldots \ldots \ldots \ldots \\
\mathrm{S} & =\frac{0.0951}{n} \ldots \ldots \ldots \ldots \ldots \ldots
\end{aligned}
$$

Table 4 showed the results of the study of the degree of dispersion. As it was observed that the dispersion coefficient(D) of the prepared ion electrode is $2.6452,[23,24]$ and this value is between (1-3) an indication that the dilution of the limited type is consistent with the use of the sensitive FMT-PTA electrode as a detector with the Flow injection analysis technique (FlA).

\subsection{Selectivity of Electrode}

Various methods can be used to calculate the selectivity coefficient $\left(\mathrm{K}_{\mathrm{i}, j}\right.$ pot $)$ for the electrode. These methods can be classified into two main classes: separate solutions methods and methods of mixed solutions. While the most common method among mixed solutions is the fixed interference method [25]. The effect of some inorganic ions such as $\left(\mathrm{K}^{+}, \mathrm{NH}_{4}{ }^{+}, \mathrm{Ca}^{++}\right.$, $\mathrm{Ba}^{++}, \mathrm{Mg}^{++}, \mathrm{Al}^{+++}, \mathrm{Fe}^{+++}$, sucrose and maltose) was studied on the electrode response. Table 5 indicates that the prepared electrode has a high sensitivity and selectivity towards the drug solution without being affected by the added interfering ions. The evidence is that the values of the selectivity coefficient obtained with all ions were less than one. 
Table 4: results of measuring the degree of dispersion

\begin{tabular}{|c|c|c|c|c|c|}
\hline Ele & Conc. (M) & $\mathrm{H}^{\circ}$ & Hmax & D & Mean \\
\hline \multirow{6}{*}{$\sum_{I I}^{E}$} & $10^{-1}$ & 451 & 440 & 2.5708 & \multirow{6}{*}{\begin{tabular}{l} 
Ũ \\
\multirow{f}{0}{} \\
ஸे
\end{tabular}} \\
\hline & $10^{-2}$ & 420 & 406 & 2.6755 & \\
\hline & $10^{-3}$ & 388 & 373 & 2.7055 & \\
\hline & $10^{-4}$ & 354 & 339 & 2.7055 & \\
\hline & $10^{-5}$ & 317 & 306 & 2.5708 & \\
\hline & $10^{-6}$ & 385 & 272 & 2.6433 & \\
\hline
\end{tabular}

Table 5: the selectivity factor of potentiometric for some of the added ions.

\begin{tabular}{ccc}
\hline \multirow{2}{*}{$\begin{array}{c}\text { A.ion } \\
0.01 \mathrm{M}\end{array}$} & \multicolumn{2}{c}{$\mathrm{K}_{\mathrm{i}, \mathrm{j}}$ pot } \\
\cline { 2 - 3 } & Ion Con & Ion Con \\
& $0.01 \mathrm{M})$ & $(0.001 \mathrm{M})$ \\
\hline $\mathrm{K}^{+}$ & 0.0073 & 0.0018 \\
$\mathrm{NH}_{4}^{+}$ & 0.0244 & 0.0032 \\
$\mathrm{Ca}^{+2}$ & 0.0350 & 0.0040 \\
$\mathrm{Mg}^{+2}$ & -0.0363 & -0.0025 \\
$\mathrm{Ba}^{+2}$ & 0.1239 & 0.0022 \\
$\mathrm{Fe}^{+3}$ & 0.0333 & 0.0015 \\
$\mathrm{Al}^{+3}$ & 0.0234 & 0.0034 \\
sucrose & 0.1131 & 0.0448 \\
maltose & 0.1391 & 0.0015 \\
\hline
\end{tabular}

\subsection{Analytical Applications}

Two methods have been applied to estimate famotidine in pharmaceutical preparations (tablets) using the coated graphite electrode as a branched unit in the FlA system of these methods: the direct method which includes injection of a concentration $\left(1.0 \times 10^{-2}, 1.0 \times 10^{-3}\right.$ M) of the preparative that was previously prepared into the carrier current via plastic syringe. The other method is the standard addition method (one addition). The results of two methods are shown in Table 6 . The results showed that in both methods the average of recovery of FMT in pharmaceutical tablets was (97.25 - 102.87\%), while the relative standard deviation did not exceed $0.9698 \%$. This indicates that the proposed method has been successfully applied to estimate FMT in its pharmaceutical and commercial preparatives.

Table 6: An analytical application of the proposed method for estimating FMT in the form of pharmaceutical tablets.

\begin{tabular}{|c|c|c|c|c|c|}
\hline Forms & method & Taken(M) & Found(M) & RSD \% & $\operatorname{Rec} \%$ \\
\hline \multirow{4}{*}{ 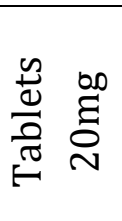 } & \multirow{2}{*}{ (a (l } & $10^{-2}$ & $0.972 \times 10^{-2}$ & 0.9698 & 97.25 \\
\hline & & $10^{-3}$ & $1.028 \times 10^{-3}$ & 0.8116 & 102.87 \\
\hline & \multirow{2}{*}{ (ll)b } & $10^{-3}$ & $1.003 \times 10^{-3}$ & 0.5219 & 100.39 \\
\hline & & $10^{-4}$ & $0.989 \times 10^{-4}$ & 0.6359 & 98.905 \\
\hline
\end{tabular}

a. method (I): direct method.

b. method(Il): the standard addition method (one addition).

\section{Conclusions:}

In the present work, the electrochemical method was developed by preparing the coated graphite electrode and using it as a detector within the Flow Injection Analysis System (FlA). It also indicated that the prepared electrode has high sensitivity and selectivity towards its ions. Also, this method achieved a good flow rate in small injection volumes and in a short time. While Rec\% and RSD\% showed that this method is of high accuracy and precision. shortly, the proposed method has many advantages including (sensitivity, simplicity, selectivity, lower response time, accurate results, low cost). Consequently, this method can be successfully applied in routine analysis of FMT in its pure form and its pharmaceutical preparatives. 


\section{References}

1. Pharmacopeia, B. (2013). System Simulation Ltd, the Stationary Office Ltd. London, I, 1035.

2. Sweetman, S. C. (Ed.). (2009). Martindale: the complete drug reference (Vol. 3709). London: Pharmaceutical press.

3. Campoli-Richards, D. M., and Clissold, S. P. (1986). Famotidine. Drugs, 32(3), 197-221.

4. Kamath, B. V., Shivram, K., and Vangani, S. (1992). Spectrophotometry determination of famotidine by charge transfer complexation. Analytical letters, 25(12), 2239-2247.

5. Alhelfi, A., and Aljabar, R. A. (2016). Anew spectrophotometric method for determination of Famotidine drug. karbala journal of pharmaceutical sciences, (11), 1525.

6. Al-Abachi, M. Q., Mohmmed, S. S., and Hadi, A. J. (2015). The spectrophotometric determination of Famotidine drug via coupling with diazotized metochlopramide hydrochloride. Baghdad Science Journal, 12(4), 730-739.

7. Alamgir, M., Khuhawar, M. Y., Memon, S. Q., Hayat, A., and Zounr, R. A. (2015). Spectrofluorimetric analysis of famotidine in pharmaceutical preparations and biological fluids by derivatization with benzoin. Spectrochimica Acta Part A: Molecular and Biomolecular Spectroscopy, 134, 449-452.

8. Wadher, S. J., Kalyankar, T. M., Kshirsagar, J. R., and Anitha, K. (2017). Simultaneous Determination of Famotidine and Dicyclomine $\mathrm{HCl}$ in combined Tablet Dosage form by UV-Spectrophotometer. Research Journal of Pharmacy and Technology, 10(2), 408-413.

9. Hassan, A. I. (2019). Utility of N-Bromosuccinimide as a Green Chemical Reagent for Determination of H2-Receptor Antagonists in their Pharmaceutical Dosage Forms. Acta Chemica Iasi, 27(1), 47-64.

10. Kontou, M., and Zotou, A. (2017). Use of a monolithic column for the development and validation of a HPLC method for the determination of famotidine, cimetidine and nizatidine in biological fluids. Journal of Applied Bioanalysis, 3(4), 1856.

11. Abass, S. A. E., Walash, M. I., and Ibrahim, F. (2016). Development and Validation of Spectrophotometric and Pre-column Derivatization HPLC Method for Determination of Famotidine in Pharmaceuticals by Reaction with Sodium Nitroprusside; Application to Combined Tablets. Pharm Anal Acta, 7(5), 476.

12. Alamgir, M. Y. K. M., Khuhawar, M. Y., Memon, S. Q., Hayat, A., and Zounr, R. A. (2017). HPLC Determination of Metformin, Famotidine and Ranitidine by Derivatization with Benzoin from Drugs and Biological Samples. Pharm Anal Acta, 8(546), 2.

13. Chhalotiya, U. K., Patel, D. B., Shah, D. A., Mehta, F. A., and Bhatt, K. K. (2017). TLC Method for simultaneous quantification of chlorzoxazone, paracetamol, famotidine and diclofenac potassium in their combined dosage form. Austin Chromatogr, 4(1), 1044.

14. Hanif, M., Nazer, N., Chaurasiya, V., and Zia, U. (2016). Simultaneous determination of famotidine and flurbiprofen by high performance liquid chromatography. Tropical Journal of Pharmaceutical Research, 15(3), 605-611.

15. Helali, N., Adhoum, N., and Monser, L. (2005). Flow injection kinetic spectrophotometric method for the determination of famotidine in pharmaceutical preparations. Journal of Flow Injection Analysis, 22(2), 129.

16. David, I. G., Popa, D. E., Calin, A. A., Buleandra, M., and Iorgulescu, E. E. (2016). Voltammetric determination of famotidine on a disposable pencil graphite electrode. Turkish Journal of Chemistry, 40(1), 125-135. 
17. Garg, A., Kumar, Y., and Pandey, R. (2015). Study of Pb 2+-Famotidine Complexes by Polarography. Journal of Advanced Chemical Sciences, 97-99.

18. Ayad, M. M., Shalaby, A., Abdellatef, H. E., and Elsaid, H. M. (2002). Potentiometric determination of famotidine in pharmaceutical formulations. Journal of pharmaceutical and biomedical analysis, 29(1-2), 247-254.

19. Kamath, B. V., Shivram, K., and Shah, A. C. (1994). Determination of diclofenac sodium, famotidine and ketorolac tromethamine by flow injection analysis using dichloronitrophenol. Journal of pharmaceutical and biomedical analysis, 12(3), 343346.

20. Kamath, B. V., Shivram, K., and Vangani, S. (1993). Flow injection analysis of famotidine with spectrophotometric detection. Analytical letters, 26(10), 2183-2191.

21. Santini, A. O., Pezza, H. R., De Oliveira, J. E., and Pezza, L. (2008). Development of a potentiometric flufenamate ISE and its application to pharmaceutical and clinical analyses. Journal of the Brazilian Chemical Society, 19(1), 162-168.

22. Alattabi, A. W., Harris, C. B., Alkhaddar, R. M., Hashim, K. S., Ortoneda-Pedrola, M., and Phipps, D. (2017). Improving sludge settleability by introducing an innovative, twostage settling sequencing batch reactor. Journal of water process engineering, 20, 207216.

23. Trojanowicz, M., and Matuszewski, W. (1983). Potentiometric flow-injection determination of chloride. Analytica Chimica Acta, 151, 77-84.

24. Ruzicka, J., and Hansen, E. H. (1988). Flow injection analysis (Vol. 104). John Wiley and Sons.

25. Guilbault, G., Durst, R., Frant, M., and Thomas, J. D. R. (1976). IUPAC technical reports and recommendations. Pure and Appl. Chem, 48, 127. 
تقدير الفاموتيدين في المحاليل النقية والمستحضرات الصيدلاتية باستعمال قطب الكرافيت المطلي كمكشاف في منظومة (FlA)

$$
\text { أحمد علي يونس* ، شذى يونس السامرائي }
$$

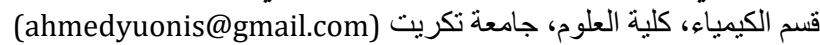

البحث مستل من رسالة ماجستير الباحث الكعة الاول

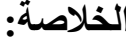

تم تطوير طريقة الكهروكيميائية البسيطة لتقدير الفاموتيدين في المحاليل النقية

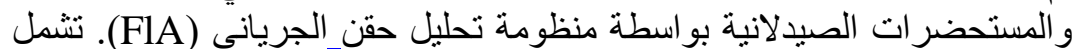

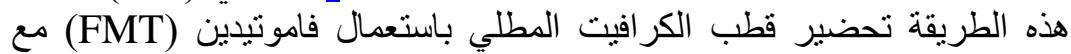

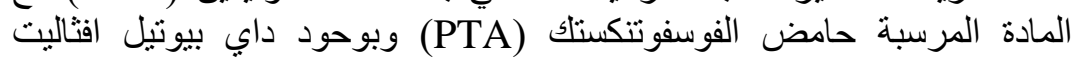

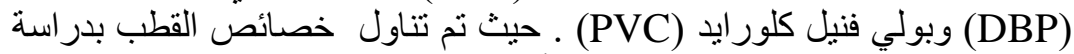
الظروف المثلى ، تيار الناقل ، وحجم الأنموذج المحقن، وسر عة الجريان، وطول ولنول

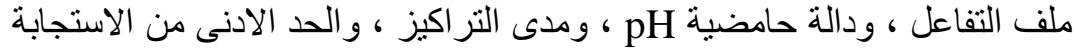

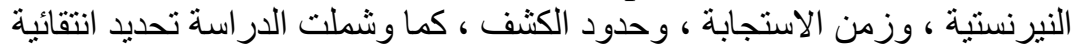
القطب باتجاه الايونات المتداخلة الاخرى. اظهرت القدات القطب ان افضل ميل نيرنست

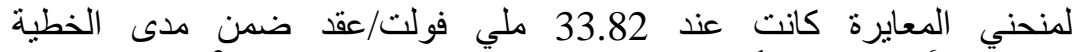

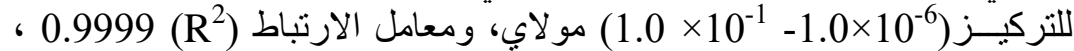

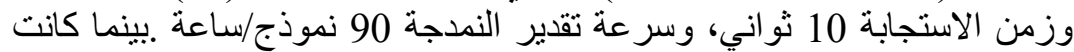

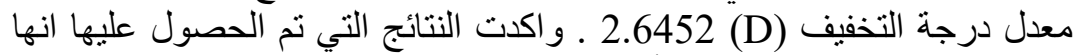

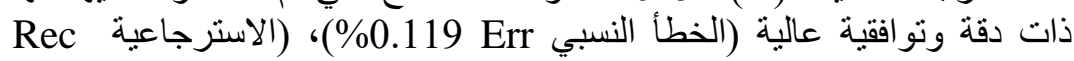

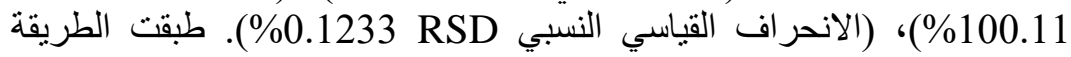
المقترحة بنجاح لتقدير فاموتيدين في اشكال اقر اص التي التجارية.
معلومات البحث:

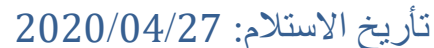

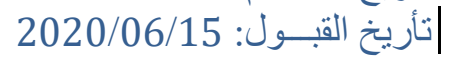

\section{الكلمات المفتاحية:}

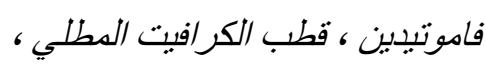
تحلبل بالحقن الجربانسي ، غطباء

(PVC) 